\title{
Xenotransplantation - Ethical Considerations based on Human and Societal Perspectives
}

\author{
By Matthias Kaiser
}

The National Committee for Research Ethics in Science and Technology (NENT), Box 522 Sentrum, N-0105 Oslo, Norway.

E-mail: matthias.kaiser@etikkom.no

\section{Introduction}

Xenotransplantation marks a qualitatively new challenge in medical technology assessment. The reasons for this claim are twofold: (i) in contrast to more traditional medical interventions, xenotransplantation involves risks not only to the patient, but also to larger segments of society, thus to public health in general. (ii) while most medical technologies demand assessment and risk-management at the time when the technology is sufficiently developed to be put into practice, xenotransplantation demands pro-active action at a very early stage of development.

A particular challenge for any assessment of xenotransplantation is the inclusion of a satisfactory approach to the ethical issues involved. In itself this is, of course, not particular/unique to xenotransplantation, as most medical interventions need a good consideration of ethics. But seen in connection with the two characteristics mentioned above, this amounts to a truly formidable task.

Given that discussions about xenotransplantation are rather recent, and given that a real scientific development is - luckily I am inclined to say - still pending and assumedly not to be expected for several years to come, it is not surprising that the debate about the ethics involved is still very tentative. Several academic papers and several government reports from a variety of countries do indeed deal with the ethical issues of xenotransplantation. But it is, as far as I can see, still too early to say that a general consensus has been reached about what precisely the ethical issues are, and, more importantly, how best to deal with them. What is important, though, is that the discussion about ethics in xenotransplantation has started, and that it follows the medical-scientific advances very closely. This is in itself a consoling reminder that ethical awareness in modern societies is coming more and more to the fore front of public debate, and that ethics is put on the agenda, including the political agenda, like never before.

In this paper I shall leave out a number of ethical issues that need to be dealt with if the ethical assessment is to be comprehensive. These are e.g. issues concerning animal welfare and ethics, issues concerning standard medical ethics about how to prepare patients for serious medical interventions, or issues concerning what could be considered a equitable distribution of scarce organ resources. With the exception of animal ethics, none of these seem to be specific to xenotransplantation. Rather, I shall concentrate on three salient issues that I deem to be decisive for any acceptable treatment of ethical issues with regard to xenotransplantation. The first issue is the often heard "playing 
God"-argument and variants of it that I shall discuss critically. The second and most important issue is the public health risks, and the adoption of the Precautionary Principle. I shall argue for the use of the Precautionary Principle in this case. The last major theme that shall be covered in the presentation is the issue of acceptable decision-making about xenotransplantation. It is argued that a broad initiative to stimulate public debate on the topic is needed in order to provide for a democratically satisfactory justification for eventual regulation etc. A wide variety of participatory tools already exist, and what is lacking, is basically the will and power commitment of those in charge of public health policy.

\section{Ethical judgement}

Ethics designates the concept of moral judgements in a coherent web of inter-connected principles. Ethics deals with issues of right or wrong, good or bad, related to a definite choice of different options $(2,25)$. Ethical judgements fall into one of three categories: morally right, morally wrong, or morally neutral. For a judgement to be a good moral judgement it takes three essential ingredients:

i. Sufficient information / knowledge concerning the situation and the options;

ii. Ethical argument or explicit use of ethical principles;

iii. Moral competence and skill.

Element (i) relates normally to the inclusion of good (scientific) expertise. Without knowledge, or at least the attempt to gather relevant knowledge, no moral judgement can be deemed good. The second element relates to normative rationality and the consideration of pro and con arguments, as well as such considerations as consistency, universality etc. The last element relates to such properties as e.g. empathy and to view situations from different angles etc. Some people are better at this than others, but as individual competence, it is independent of any particular theoretical expertise. In other words, all people have this competence.

The question then arises, what role ethical theories may play in this? The first thing to realize is, that there is obviously a multitude of ethical theories. We differentiate between deontological (e.g. Kant) and consequentialist (e.g. Bentham or Mill; utilitarianism) ethical theories, virtue ethics (Aristotle), justice centred ethical theories (Rawls; justice as fairness), Christian ethics versus humanist ethics etc. A theory of values is not directly identical to any of these theories, since e.g. utilitarianism is consistent with a multitude of sets of values, but the existence of some of these values is always implied in ethics. Basically, ethics deals with different concepts of the good life. The problem is, that there is no obvious candidate among these theories of ethics that a) will provide good answers to all ethical problems, and that b) people will agree upon.

We need, though, to make ethical decisions, even when not agreeing on a good theory of ethics, or on the most important ethical principles. Amazingly, it turns out that, while people disagree immensely on ethical principles, basic value, and general ethical outlook, they also tend to be in much larger agreement when confronted with specific cases of ethical dilemma. It was, in fact, the most striking experience in newly established committees on medical ethics, that they could agree on certain recommendations with a large consensus among members, while they seemed to disagree as soon as they were asked to justify their decision (10; p.16ff). Primary ethical theories remain thus contested, while concrete and socially robust judgements seem possible on a much weaker basis.

This has led to the development of practical ethics. One approach is so-called principle- 
based ethics. The idea is to import a number of ethical principles, and use them isolated from the rest of their theoretical superstructure for solving specific dilemmas. One such approach is the ethical matrix that we shall use further down. Here it is important to state, if only for the sake of the argument, that the used principles represent only an approximation to fullfledged theories. The claim is that this will make little practical difference in most cases. Let us now look closer at xenotransplantation.

\section{Ethical issues in xenotransplantation}

I can see three major clusters of ethical issues in xenotransplantation:

1) Is it at all ethically justifiable to perform xenotransplantation on a large scale, assuming the technology will ever be available?

2) Given that xenotransplantation is ethically justified in principle, is it then also ethically justified to perform clinical experiments while scientific uncertainties still appear large?

3) Are all accompanying measures and strategies that might follow the development and practice of xenotransplantation (animal experiments with primates, restrictions of personal freedom after surgery, monitoring of close relatives or sex-partners, etc.) ethically justified in themselves?

I shall not deal with 2) and 3) in this paper, but I shall concentrate on 1), more specifically, those aspects of 1) that relate to risk (thus touching on issue 2 after all) and human nature, excluding e.g. animal welfare. I hope, though, that the approach suggested here might indicate how I think that one can deal with other issues as well.

There are two aspects of xenotransplantation that make it a special challenge to ethics, quite detached from other medical technologies so far developed. First of all, xenotransplantation carries with it, not only certain risks to the patient, but also to some extent risks to public safety and health. This is due to the theoretical possibility of zoonosis (in this case more correctly "xenosis"), i.e. the transferral of virus from the source organism (where these viruses may or may not cause disease) to the recipient, where they eventually may cause viral infections of the recipient. Of particular concern are the so-called porcine endogene retrovirus (PERV) in transferral of pig-cells to humans. While PERVs are unproblematic for pigs, we do not know how they will behave in humans, especially if the possibility of mutation is taken into account. I shall not expand on this point, but rather refer to the other contributions in this volume and to the NOU 2001 (18) (see also 19, 23). Obviously, the absolute worst case scenario would be one in which PERVs become virulent with easy transferral of infections between humans (e.g. drop infections), with a long period of latency, and eventually fatal outcome.

The second point why xenotransplantation is a special challenge to ethical decision making, is that the uncertainties we are dealing with, are inherent in the system and not simply a matter of not having done enough research. While basic research may carry us a long way with regard to charting the necessary mechanisms for xenosis and estimating the risk of transferral from donor to recipient, we are at an impasse when PERV is transmitted without immediate negative effects. How long may the virus stay harmless? And if it turns into something dangerous, what is the period of latency, i.e. how long do we have to test and monitor the patient until we can rest assured that no harm is done? If a system has no resilience to an unknown intruder, then the system may be destabilised at any point without one being able to predict when this will happen. So is the nature of system uncertainties. Wait-and-see is simply no ethically justifiable course of action. We have to 
make decisions taking explicit account of the uncertainties, if we want to act ethically.

Before I explain my suggestion of how to deal with this challenge, let me sketch some arguments that have been put forward as an answer to these challenges, but that do not carry us very far.

\section{The "Playing God-argument" and other objections}

There is the argument that one should refrain from xenotransplantation altogether because xenotransplantation breaks down some "Godgiven" boundaries between man and animals. In so doing, we effectively re-shuffle the order of nature as intended by God, thus assuming the same status as God the creator. A divine order should not be tampered with, and consequences can only be disastrous. Interestingly, even an atheist may cling to a version of this argument, replacing God with some notion of Nature (but implicitly assuming that Nature has something like intentions).

Even though this argument is sometimes displayed in political debates, it is seldom defended by ethicists or theologians. I think the reasons are obvious: the argument is just not good enough. It is in flagrant violation of a whole lot of practices that we assumedly consider ethically well justified. We may mention allotransplantation, of course (i.e. the breaking down of the "divine order" between individuals), but also such innocent practices as animal breeding or agriculture. If we violate a divine order by transferring a pig cell from a pig to a human, then we also violate this same order when we cross Brussel-sprouts with cauliflower, or when we breed gold-fish with dysfunctional tail-fins.

One may counter this objection by claiming that the argument is not really an absolute argument, but basically an argument of the "slippery-slope" kind. Most people seem to agree that we do not necessarily need to let nature take its course, without us interfering and rectifying developments that we deem negative. Thus, on the one hand, nature is not "holy" (the "divine order" is not an absolute). On the other hand, most people seem also to agree that if we ourselves or the nature around us would be the sole result of human designs, then we have perverted the very core of our existence. The positive design of humans, for instance, is judged ethically unacceptable, since chance and accident is seen as a basic feature of the human condition, making for the uniqueness of each and every individual. So we have the positive design at the bottom and the repair option at the top. While the top end is unproblematic, the bottom is deemed ethically highly problematic. If we move too much away from the top, we might slide all the way down. Xenotransplantation might just be that kind of move, since we utilise other living beings for the benefit of humans in a hitherto unprecedented manner.

The problem with that kind of argument is that it rests on unrealistic premises. There is always change, we cannot stand still in history, and we are certainly not placed on a singular moral slope. Rather, we are always facing dilemmas of having to make trade-offs between various considerations, many of them highly ethically relevant, too. In this landscape we have no use for one-dimensional maps, we need multi-dimensional charts of our immediate surroundings.

There is still another version of the argument that one may try here. It runs as follows: we undermine both our and nature's inherent value if everything is treated instrumentally, e.g. pig organs. When we start to farm pigs for the sole purpose of harvesting their organs, we not only show disregard for the animal's dignity, but in effect we ourselves have become perverted in the very nature of our humanity ("doing this to others just shows what has become of you!"). 
This is an extension and variation of the wellknown Kantian categorical imperative, and it rests on essentialism.

I have some sympathy for this argument, if only as a reminder that we are but a minute part of the whole of nature. The problem with this argument in our connection is similar to the previous one: as long as we do not have a positive specification of what is an ethically legitimate instrumentalisation of nature and what is not, it does not help us much. Faced with the choice of saving a human being from certain death, and instrumentalising some colonies of pigs, the balance of moral consideration might go in favour of the human being. After all, it does so in meat production.

There may be other arguments that one might bring to the fore front against xenotransplantation as a principal option for health technologies. Some of them are surely non-starters, as e.g. the zero-risk argument: only under full certainty and with zero risk to public health should we engage in xenotransplantation. But: there is never any zero-risk in anything we engage in, and avoiding all risks at any price leads to ethically unacceptable costs under scarce resources.

Thus, all in all, I am inclined to say that seemingly there is no real ethical knock-down argument against the very possibility of performing xenotransplantation as a routine treatment. There are, on the other hand, good moral reasons why xenotransplantation should be on our agenda of medical interventions, namely the life of a great number of patients. This is not to say that we should go ahead without moral restraint in developing this technology. In fact, I believe there are good reasons why restraint is indicated. The restraint has to do with the morally acceptable way of managing the risks (uncertainties) involved. The key term here is precaution.

\section{The Precautionary Principle in medical technology}

The Precautionary Principle (hereafter: PP) was first developed to manage environmental risks of various kinds. It is integrated in various national laws and international treaties. Recently it has been extended to other uses as e.g. industrial safety and public health via considerations of the safety of food (gm-food in particular). PP is still debated in science, since it has no unique definition, and it is (thus) hard to operationalise in practise. Politically PP is also challenged by the US, against the insistence of the EU, that it is not a hindrance of technological progress, nor a new trade barrier (e.g. in the WTO). The Nordic countries largely seem to accept the PP as a sensible instrument of policy making in the realm of uncertainty. I shall not dwell on the discussions about the PP (see e.g. $6,7,8,9,11,12,13,17,20,21,22,24)$, but assume that some consensus on its basic substance can be reached. Is it, then, sensible to apply the PP in the case of xenotransplantation? One may differentiate between three major steps when utilising the PP: 1) Under what conditions do we need to apply the PP at all? 2) If the PP is applied, what precautionary strategies should be chosen? 3) Given that parts of the deliberations are sensitive to value issues, how is the decision process on the PP to take place in a democratic society?

NENT (The National Committee for Research Ethics in Science and Technology (in Norway) (17) has specified certain conditions for when to apply the PP. They are:

- there exist considerable scientific uncertainties;

- there exist scenarios (or models) of possible harm that are scientifically reasonable (i.e. based on some scientifically acceptable reasoning);

- uncertainties cannot be reduced without at 
the same time increasing ignorance of other relevant factors;

- the potential harm is sufficiently serious or even irreversible for present or future generations;

- if one delays action now, effective counteraction will later be made more difficult.

I shall attempt to provide a detailed argument why xenotransplantation can indeed be said to fulfil these conditions. Again I refer to the NOU 2001 (18) for further details. But the conclusion is, that all of these conditions seem to hold for the case of xenotransplantation. There are, as we have observed in the beginning, major system uncertainties involved, related to the transferral of PERVs and their potential for causing infections in humans. There is also a scientific basis for a harm scenario of this kind, e.g. the development of HIV by zoonosis from primates to humans. The potential harm may be very great, immediately or at a later point of time. And we do not have ways to effectively reduce the uncertainties, other than trying it out in practice. Any model situation in a laboratory only raises the question whether the model recaptures the reality. But unless we take some precautionary measures in time, we might not be able to do so once the problem has materialised. Hence, I conclude that there is sufficient reason to apply the PP in the case of xenotransplantation.

What then are the precautionary strategies that one might want to implement as a consequence? A precautionary strategy can be defined as any measure that can be believed to effectively reduce either the risk of the harm itself, or the magnitude and spreading of the harm, should it occur. The NOU 2001 (18) on xenotransplantation discusses a number of possible strategies: a moratorium, a step-by-step and a case-by-case strategy, restrictions of uses to small and strictly monitored groups, and the international cooperation in monitoring the pa- tients (and their families). The first is the strictest and the last is the most liberal, i.e. least effective strategy. As tempting as a moratorium may look from a societal point of view, it should be kept in mind that it only delays the problem. It might actually backfire, given that not all countries might implement a moratorium and that diseases know no borders. What one eventually wants to achieve is enough knowledge and a strong institutional apparatus to contain the possible harm should it materialise, but still allowing the technology to develop for the benefits of patients.

This then brings us to the question of who is to make the relevant decisions, and how is this to be done? Obviously, since value issues are at stake here, and since people have different degrees of willingness to take risks, a wide public consultation is indicated, especially in lively and modern democracies. Many individuals (e.g. 1) and several government reports have stressed the need of this public consultation (18). Canada has begun a process with public consultations on this issue (4). One of the difficult issues is how to make sure that the ethical viewpoints come out appropriately in these public consultations. Here, I suggest to consider the method of ethical matrix.

\section{An ethical matrix on xenotransplantation - a tentative suggestion}

An ethical matrix is a scheme that specifies and interprets selected and acknowledged ethical principals according to every stakeholder's viewpoint. The approach originated first in Beauchamp and Childress (3) for medical ethics, and was then further developed for biotechnological issues by Ben Mepham (15, 16), and modified by Kaiser and Forsberg (14; also 5).

The basic idea is to collect the basic ethical principles guiding our decision-making along one dimension, and to specify all the ethical 
stakeholders along another dimension. The first step, then, is to provide detailed specifications of the ethical principles for all stakeholders and all principles. For instance, given that one includes the principle of justice, and uses only two stakeholders, patients and families. In the case of xenotransplantation one could venture that justice from the patient's point of view amounts to the fair distribution of available transplant organs, while seen from the families' point of view, it could mean that their lives are not unduly and unnecessarily restricted because of one family-member's operation. It is quite easy to see that many ethical principles will lead to diverging specifications for different stakeholders. All the cells being columns under all principles, and rows next to all stakeholders, need to be filled in.

The next step is to consider how a given action, in this case a technology, will affect the ethical considerations in each cell. A given action might diminish the chances of the consideration under discussion, it might increase them, or it may be neutral to them. This is called the consequence matrix, consisting basically of "+", "" and "0"-marks in each cell. Alternatively, the relevant consequences could be spelled out in more detail.
In a final step one then needs to evaluate the totality of all the relevant considerations. This evaluation is not something that can be deduced from the matrix itself, but needs the considered judgement of those engaging in the exercise. The value of the ethical matrix lies in its feature of making the ethically relevant aspects of the choice transparent to all involved parties and structuring their debate. It is not an algorithm for decision making.

There is a real issue on the number and nature of the ethical principles that are used. I shall not enter this debate here, but only indicate that we found it useful to operate with the three principles justice (as fair distributions), dignity (including autonomy for human subjects) and welfare (including measurable benefits like economy, but being restricted to them). My suggestion would be to regard the ethical matrix as a practical tool for a process of public consultations on xenotransplantation. It could help focus the deliberations on the ethical issues and provide understanding for the different considerations that need to be taken into account. It is still an open-ended process, since it does not prescribe any particular final judgements.

As a start-up ethical matrix one might want to consider something along the following lines:

\begin{tabular}{|c|c|c|c|}
\hline & justice & dignity & welfare \\
\hline pasient & $\begin{array}{l}\text { Equal changes } \\
\text { /fair access to organs }\end{array}$ & Informed consent & $\begin{array}{l}\text { Improved } \\
\text { quiality of life }\end{array}$ \\
\hline family & $\begin{array}{l}\text { No unneccesary } \\
\text { restrictions to private } \\
\text { lives }\end{array}$ & $\begin{array}{l}\text { Informed consent } \\
\text { on restrictions }\end{array}$ & $\begin{array}{l}\text { Improved } \\
\text { quality of life } \\
\text { in family }\end{array}$ \\
\hline society & $\begin{array}{l}\text { No unvoluntary } \\
\text { risks }\end{array}$ & $\begin{array}{l}\text { Consultation / } \\
\text { information / } \\
\text { democracy }\end{array}$ & $\begin{array}{l}\text { Improved } \\
\text { public health } \\
\text { Acceptable costs }\end{array}$ \\
\hline $\begin{array}{l}\text { future } \\
\text { generations }\end{array}$ & $\begin{array}{l}\text { No inheritance } \\
\text { of non natural risks }\end{array}$ & $\begin{array}{l}\text { Possibility of } \\
\text { reversal }\end{array}$ & $\begin{array}{l}\text { Good public } \\
\text { health }\end{array}$ \\
\hline animals & $\begin{array}{l}\text { Compensated } \\
\text { for loss of wild life }\end{array}$ & $\begin{array}{l}\text { Respect of } \\
\text { basic needs }\end{array}$ & No pain \\
\hline
\end{tabular}


The second step is then to ask what xenotransplantation would do to any of the concerns expressed in the above matrix. Here one may obviously deal with a large number of relevant consequences, and some of the consequences will be uncertain, so that their estimated probability might come into play. But roughly, one could venture consequences of the following kind (that need to be evaluated in respect to the principles):

I shall refrain from any attempt to specify in detail how each consequence affects the ethical concerns of the first matrix.

My argument here is not to defend the specifics of the ethical matrices outlined above. They serve merely as an illustration of what could be the structure of a public consultation process on xenotransplantation. They cannot replace that process. But the basic point is that there are indeed "tools" of participatory and ethical decision making at hand, that could be utilised in a public consultation process, and that might indeed be useful tools in that process. And in the above sections I tried to show that the nature of the issues in xenotransplantation is such that we cannot avoid a public consultation.

\section{Conclusion}

This paper argued that the novel features of xenotransplantation set it apart from the traditional ethical evaluations of other medical technologies. The systems uncertainties, the risks, and the need for pro-active deliberations and actions requires special ethical attention. While I rejected most of the arguments that sometimes are put forward to question the very legitimacy of xenotransplantation from an ethical point of view, I argued that the Precautionary Principle offers the most relevant guidance in this case. Basically, all the conditions needed to apply this principle can be assumed to hold, and, furthermore, several precautionary measures are available. The real crux is then the decision making process in this case. Since the value issues are so central, since risks are judged differently by different people, and since interests may clash between different groups, a participatory process is indicated. In the final section I suggested that the method of ethical matrix be used to help structure this public consultation. Ethics is not a discipline of expertise as any other part of science and scholarship. It has its basis in the moral judgements that everybody

\begin{tabular}{llll}
\hline & justice & dignity & welfare \\
\hline pasient & More transplants & $\begin{array}{l}\text { Consent may } \\
\text { change over time }\end{array}$ & $\begin{array}{l}\text { Survival, even with } \\
\text { acceptable quality } \\
\text { of life }\end{array}$ \\
family & $\begin{array}{l}\text { No or few unreasonable } \\
\text { constraints } \\
\text { (uncertain) }\end{array}$ & $\begin{array}{l}\text { Loss of motivation } \\
\text { to uphold strict } \\
\text { regime over time }\end{array}$ & $\begin{array}{l}\text { Improved quality } \\
\text { in family, but also } \\
\text { additional strain }\end{array}$ \\
society & $\begin{array}{l}\text { Unvoluntary and } \\
\text { large risks }\end{array}$ & $\begin{array}{l}\text { Some groups } \\
\text { principally opposed }\end{array}$ & $\begin{array}{l}\text { Uncertain net-effect } \\
\text { in health economy }\end{array}$ \\
future & Unvoluntary risks & $\begin{array}{l}\text { Practically } \\
\text { inreversible risks }\end{array}$ & $\begin{array}{l}\text { Strain on their } \\
\text { health economy } \\
\text { possible? }\end{array}$ \\
& inherited & Limited satisfaction \\
animals & Some & Pain and \\
& compensation & artificial environment & suffering \\
\hline
\end{tabular}


makes to a larger or lesser extent in daily life. But there are constraints and conceptual frameworks in ethics that help people make better ethical judgements. The challenge in the case of xenotransplantation is to utilise these constraints and frameworks in a process of building consensus on the restrained, careful and precautionary development of a public policy for xenotransplantation. The earlier this process starts the better. We cannot wait until the technology is fully developed.

\section{References}

1. Bach, FH, Fineberg HV: Call for moratorium on xenotransplants, Nature 1998, 392, 11-12.

2. Baune Ø: Etisk argumentasjon, 5. rev. utg. Oslo: Ø. Baune, 1990.

3. Beauchamp TL, Childress JF: Principles of biomedical ethics. 4th ed. Oxford: Oxford University Press, 1994.

4. Einsiedel E, Ross H: Animal spare parts? A Canadian public consultation on xenotransplantation. Sci. Eng. Ethics 2002, 8, 579-591.

5. Forsberg EM, Kaiser M: Norske fiskerier mot 2020 - verdier og strategier. Oslo: De nasjonale forskningsetiske komiteer, publikasjon nr. 8, 2000.

6. Foundations of Science (special issue): Kaiser M (ed.). The precautionary principle and its implications for science. 1997, 2 (2).

7. Freestone D, Hey E: (eds.). The precautionary principle and international law - The challenge of implementation. The Hague: Kluwer Law International, 1996.

8. Harremoës $P$ et al. (eds). Late lessons from early warnings: the precautionary principle. Copenhagen: European Environment Agency, 2001. Environmental issue report no. 22.

9. Kaiser M: (ed.). The precautionary principle. J. agr. Environ. Ethics (special issue), 2002, 15 (1).

10. Jonsen AR, Toulmin $S$ : The abuse of casuistry. (2001) Journal of Risk Research, special issue: The precautionary principle, (ed. J.D. Graham), 1988, 4, 2.
11. Graham JD: (ed.). The precautionary principle. J. Risk Res. (special issue), 2001, 4, (2).

12. Kaiser M: Fish-farming and the precautionary principle: Context and values in environmental science for policy. Foundations of Science 1997, 2, 307-341.

13. Kaiser M: Ethics, science, and precaution - A viewpoint from Norway. In: Tickner 2003.

14. Kaiser M, Forsberg EM: Assessing fisheries using an ethical matrix in a participatory process. J. agr. Environ. Ethics 2001, 14, 191-200.

15. Mepham B. (ed.) Food ethics. London: Routledge, 1996

16. Mepham B. Ethical impacts of biotechnology in dairying. In: Phillips CJC (ed.). Progress in dairy sciences. Wallingford: CAB International, 1996.

17. Føre-var prinsippet: mellom forskning og politikk. Oslo: De nasjonale forskningsetiske komiteer 1997. (forthcoming in an English translation in 2002 at www.etikkom.no)

18. Xenotransplantasjon; medisinsk bruk av levende celler, vev og organer fra dyr. Oslo, 2001 (NOU 2001; 18).

19. Xenotransplantation - International policy issues, OECD: Paris, 1999.

20. O'Riordan T, Cameron J. (eds). Interpreting the precautionary principle. London: Earthscan Publications Ltd., 1994.

21. Raffensperger C, Tickner J: Protecting human health and the environment - Implementing the precautionary principle. Island Press: Washington DC, 1999.

22. Sandin $P$ : Dimensions of the precautionary principle. Hum. Ecol. Risk Assess. 1999, 5, 889-907.

23. SOU 2000: 103, Att spränga gränser - Bioteknikens möiligheter och risker, Slutbetänkande av Bioteknikkommittén, Stockholm: Utbildningsdepartementet, 2000.

24. Tickner J: (ed). Precaution, environmental science, and preventive public policy. Island Press: Washington DC, 2003.

25. Weston A. A 21 st century ethical toolbox. Oxford: Oxford University Press, 2001. 